\title{
The biomass burning contribution to climate-carbon-cycle feedback
}

\author{
Sandy P. Harrison ${ }^{1}$, Patrick J. Bartlein ${ }^{2}$, Victor Brovkin ${ }^{3}$, Sander Houweling ${ }^{4}$, Silvia Kloster ${ }^{3}$, and I. \\ Colin Prentice $^{5}$ \\ ${ }^{1}$ Department of Geography and Environmental Science, University of Reading, Whiteknights, Reading, RG6 \\ $6 \mathrm{AB}, \mathrm{UK}$ \\ ${ }^{2}$ Department of Geography, University of Oregon, Eugene, Oregon 97403-1251, USA \\ ${ }^{3}$ Max Planck Institute for Meteorology, Bundesstraße 53, 20146 Hamburg, Germany \\ ${ }^{4}$ Department of Earth Sciences, Vrije Universiteit Amsterdam, De Boelelaan 1085, 1081 HV Amsterdam, The \\ Netherlands \\ ${ }^{5}$ AXA Chair of Biosphere and Climate Impacts, Department of Life Sciences, Imperial College London, Ascot, \\ SL5 7PY, UK
}

Correspondence: Sandy P. Harrison (s.p.harrison@ reading.ac.uk)

Received: 18 February 2018 - Discussion started: 26 February 2018

Accepted: 28 April 2018 - Published: 28 May 2018

\begin{abstract}
Temperature exerts strong controls on the incidence and severity of fire. All else equal, warming is expected to increase fire-related carbon emissions, and thereby atmospheric $\mathrm{CO}_{2}$. But the magnitude of this feedback is very poorly known. We use a single-box model of the land biosphere to quantify this positive feedback from satellite-based estimates of biomass burning emissions for 2000-2014 CE and from sedimentary charcoal records for the millennium before the industrial period. We derive an estimate of the centennial-scale feedback strength of $6.5 \pm 3.4 \mathrm{ppm} \mathrm{CO}_{2}$ per degree of land temperature increase, based on the satellite data. However, this estimate is poorly constrained, and is largely driven by the well-documented dependence of tropical deforestation and peat fires (primarily anthropogenic) on climate variability patterns linked to the El Niño-Southern Oscillation. Palaeo-data from pre-industrial times provide the opportunity to assess the fire-related climatecarbon-cycle feedback over a longer period, with less pervasive human impacts. Past biomass burning can be quantified based on variations in either the concentration and isotopic composition of methane in ice cores (with assumptions about the isotopic signatures of different methane sources) or the abundances of charcoal preserved in sediments, which reflect landscape-scale changes in burnt biomass. These two data sources are shown here to be coherent with one another. The more numerous data from sedimentary charcoal, expressed as normalized anomalies (fractional deviations from the long-term mean), are then used - together with an estimate of mean biomass burning derived from methane isotope data - to infer a feedback strength of $5.6 \pm 3.2 \mathrm{ppm} \mathrm{CO}_{2}$ per degree of land temperature and (for a climate sensitivity of $2.8 \mathrm{~K}$ ) a gain of $0.09 \pm 0.05$. This finding indicates that the positive carbon cycle feedback from increased fire provides a substantial contribution to the overall climatecarbon-cycle feedback on centennial timescales. Although the feedback estimates from palaeo- and satellite-era data are in agreement, this is likely fortuitous because of the pervasive influence of human activities on fire regimes during recent decades.
\end{abstract}




\section{Introduction}

Fire is a natural, recurring event in most terrestrial ecosystems. About $4 \%$ of the global land area is burnt every year (Giglio et al., 2013), resulting in global $\mathrm{CO}_{2}$ emissions of around $2 \mathrm{PgC}$ per year (van der Werf et al., 2010), substantial contributions to the budgets of other direct or indirect greenhouse gases (including $\mathrm{CH}_{4}, \mathrm{CO}, \mathrm{N}_{2} \mathrm{O}$, and ozone precursors), and further contributions to the atmospheric aerosol loading (black carbon, organic compounds). Climateinduced inter-annual variability in biomass burning, particularly variability associated with the El Niño-Southern Oscillation (ENSO), is an important component of the inter-annual variability of the atmospheric $\mathrm{CO}_{2}$ growth rate (van der Werf et al., 2010). However, changes in biomass burning also occur in response to longer-term climate variability and trends (Marlon et al., 2008, 2013; Power et al., 2008; Mooney et al., 2011; Daniau et al., 2012). Changes in biomass burning therefore need to be taken into account in estimating the "climate-carbon-cycle feedback", i.e. the longer-term positive feedback by which global warming leads to a reduction in land carbon storage, a consequent reduction in the net uptake of $\mathrm{CO}_{2}$ so that more $\mathrm{CO}_{2}$ remains in the atmosphere, and thus an amplification of the initial warming (Arora et al., 2013; Cox et al., 2013; Wenzel et al., 2014). The dominant terms in the terrestrial carbon balance are gross primary production and total ecosystem respiration. The climate-carboncycle feedback is generally attributed to the temperaturedependent balance of these two large annual fluxes (Keenan et al., 2016; Ballantyne et al., 2017; Jung et al., 2017); but this neglects the potential contribution of biomass burning, which we consider here.

Although there have been attempts to quantify the contribution of deforestation fires (Bowman et al., 2009) or the aerosol-related component of biomass burning (Arneth et al., 2010), the global-scale contribution of biomass burning to the climate-carbon-cycle feedback has been quantified only once (Ward et al., 2012). That study reported a variety of feedbacks based on simulations using a single Earth system model (ESM). Ward et al. (2012) found that the simulated total climate feedback due to fire was negative, but their conclusion rested mainly on a large (and highly uncertain: Boucher et al., 2013; Carslaw et al., 2013; Lee et al., 2016) indirect aerosol effect that exceeded the simulated fire feedback through the carbon cycle. In contrast, Arneth et al. (2010) estimated the aerosol feedback from biomass burning to be small and of uncertain sign.

Remotely sensed observations of biomass burning offer a uniquely detailed global perspective on fire regimes. However, they cover only a limited period, and our ability to use these records to derive an empirical estimate of the biomass burning contribution to the carbon cycle feedback is further compromised by the complexity of the controls on fire. Climate influences the occurrence and magnitude of fires on daily to seasonal timescales; both climate and fire affect veg- etation productivity and hence the availability of fuel on yearly to decadal timescales; and human activities increase ignitions but more importantly decrease fuel availability and fire spread (Bistinas et al., 2014: Knorr et al., 2014; Andela et al., 2017). Analyses of the independent influence of individual controls, when other factors are held constant, show that burnt area and biomass burning is extremely sensitive to, and positively correlated with, spatial and temporal variations in global temperature (Krawchuk et al.. 2009; Daniau et al., 2012; Bistinas et al., 2014). Regional analyses also show positive relationships between biomass burning and temperature, although the strength of this relationship relative to other controls on fire varies between regions (see, e.g., Marlon et al., 2013). The overwhelming importance of temperature for fire regimes is unsurprising given that temperature changes influence atmospheric circulation patterns and are closely tied to changes in precipitation and surface climates (Held and Soden, 2006; Li et al., 2013). The positive relationship between temperature and fire at global and regional scales suggests that the contribution of fire to the climate-carbon-cycle feedback is likely to be positive. Yet burnt area has declined over the last decade. This decline has been attributed to the effects of fire suppression and landscape fragmentation outweighing the influence of climateinduced changes in biomass burning (Andela et al., 2017).

The use of palaeo-climate records obviates the problem of limited record length and avoids those various human influences that have been so large as to dominate the fire record over at least the past 150 years (Marlon et al., 2008). Ice cores provide direct evidence for past changes in atmospheric composition, and the concentration and stable carbon-isotope composition of methane $\left(\mathrm{CH}_{4}\right)$ in ice cores have been used together to reconstruct changes in biomass burning during the last millennium: see Rubino et al. (2016) for a review. $\mathrm{CH}_{4}$ is released during the smouldering phase of fires, roughly in proportion to total $\mathrm{CO}_{2}$ emission (Andreae and Merlet, 2001). Although this process is a relatively minor contributor to total atmospheric $\mathrm{CH}_{4}$, it disproportionately influences the ${ }^{13} \mathrm{C}$ content of $\mathrm{CH}_{4}$ because pyrogenic $\mathrm{CH}_{4}$ carries the isotopic signature of photosynthesis. This is much less negative than that of the dominant (microbial) sources of $\mathrm{CH}_{4}$ (Barker and Fritz, 1981). But measurements of the ${ }^{13} \mathrm{C}$ content of $\mathrm{CH}_{4}$ in ice cores are currently available with limited temporal resolution and are subject to large uncertainties in the isotopic fractionation factors for different $\mathrm{CH}_{4}$ sources. The abundance of sedimentary charcoal provides an alternative and more direct measure of relative changes in biomass burning (Power et al., 2008; Harrison et al., 2010) and has been shown to mirror changes in biomass burning $\mathrm{CH}_{4}$ (Wang et al., 2010). Sedimentary charcoal data are far more numerous than ice-core isotopic records for the last millennium. If it is possible to establish a quantitative relationship between charcoal abundance and biomass burning $\mathrm{CH}_{4}$, it should then be worthwhile to exploit the greater number and temporal resolution of these 
records to quantify the fire contribution to the carbon-climate feedback. This is the approach we adopt in this paper. We use a single-box model of the land biosphere to derive an estimate of the contemporary biomass burning contribution to the climate-carbon-cycle feedback using remote-sensingbased estimates of biomass burning carbon emissions for the interval 2000-2014 CE. We then demonstrate that the charcoal and methane records of biomass burning during the preindustrial Common Era (1-1700 CE) are in good agreement. Finally, we exploit a good correlation of normalized anomalies of global charcoal abundance with global land temperatures during the last millennium to derive an alternative estimate of the strength of the climate-carbon-cycle feedback.

\section{Data and methods}

We use a single-box model of the land biosphere to quantify the fire feedback, making separate calculations of the feedback strength and gain for the satellite-era and the preindustrial period (Fig. 1). Feedback strength is measured as the increase in atmospheric $\mathrm{CO}_{2}$ concentration (ppm) per degree increase in temperature $(\mathrm{K})$. In the satellite era, we use the relationship between the satellite-derived fire emissions and land temperature to estimate feedback strength, with a correction for the fact that land temperature variations are stronger than global mean temperature variations. We then convert feedback strength to gain, assuming well-founded values for the total biomass, airborne fraction, climate sensitivity, and atmospheric $\mathrm{CO}_{2}$ concentration (Fig. 1a). We follow the same approach for the pre-industrial era (Fig. 1b), but using sedimentary charcoal data to estimate variations in fire emissions. Use of the sedimentary charcoal data in this way is predicated on our demonstration here that there is a strong statistical relationship, conforming to an expected mathematical form, between the charcoal data and the ice-core record of atmospheric methane and its stable carbon-isotope composition.

\subsection{Remotely sensed burned area and carbon emissions}

Burnt area and carbon emissions for 2000 to 2014 were derived from the GFED4s database (Randerson et al., 2015, http://www.geo.vu.nl/ gwerf/GFED/GFED4/, last access: 16 February 2018). GFED4s provides monthly burnt area estimates on a $0.5^{\circ}$ spatial grid from 1997 through 2014, but prior to August 2000 these observations were derived by calibrating the Along Track Scanning Radiometers (ATSR) and the Visible and Infrared Scanner (VIRS) active fire data against MODIS-derived burnt area (van der Werf et al., 2017). We therefore exclude the pre-MODIS period 1997 to 1999 because of the large uncertainties in the burnt-area and emission estimates (Giglio et al., 2013). We also test whether the retention of the mixed-source estimates for 2000 (with only 5 months from MODIS) has an impact on the results (Supplement, Sect. 8). Carbon emissions in GFED4s are divided into source sectors: savannah, grassland, and shrubland fires; boreal forest fires; temperate forest fires; deforestation fires; peatland fires; agricultural fires. The estimates we use for total fire emissions include all of these sectors except agricultural fires. We exclude agricultural fires on the assumption that these are only started by people and therefore that the incidence, timing, and size of these fires are unrelated to climate or other environmental factors. We also use an estimate of the total emissions from natural sources, that is, also excluding deforestation and peatland fires. Global mean land temperatures for this period, for comparison with the fire data, were taken from the NOAA Merged Land Ocean Global Surface Temperature Analysis (NOAAGlobalTemp v4.0.1, https://doi.org/10.7289/V5FN144H; Vose et al. 2012): https://www.ncdc.noaa.gov/data-access/marineocean-data/ noaa-global-surface-temperature-noaaglobaltemp (last access: 16 February 2018), with specific data found at http:// www1.ncdc.noaa.gov/pub/data/noaaglobaltemp/operational/ (last access: 16 February 2018).

\subsection{Charcoal data}

The sedimentary charcoal data were obtained from version GCDv3 of the Global Charcoal Database (Marlon et al., 2016). This new version of the database contains considerably more individual site records than previous versions and provides better spatial coverage. Charcoal data were read directly from the database file GCDv03_Marlon_et_al_2015.mdb. The data were processed using the protocol described in Power et al. (2010) and Blarquez et al. (2014) except that the transformed charcoal influx values (or their equivalents) were expressed as normalized anomalies (normans, $N_{t}$ at time $t$ ) or

$N_{t}=\left(c_{t}^{*}-\bar{c}^{*}\right) / \bar{c}^{*}$,

where the $c_{t}^{*}$ is the optimally Box-Cox-transformed influx values from a particular record at time $t$, and $\bar{c}^{*}$ is the mean transformed influx for that record over the interval 1$1700 \mathrm{CE}$ (the transformation and normalization base period). A 10-year interval was used for pre-binning the 633 records used for the creation of the composite curve.

\subsection{Methane concentration and stable carbon-isotope data}

Methane concentration data were taken from the composite Law Dome records (Etheridge et al., 2010). We used a composite data set of $\delta^{13} \mathrm{C}$ of $\mathrm{CH}_{4}$ from Ferretti et al. (2005), Mischler et al. (2009), and Sapart et al. (2012). We used the published age models for each record. We then applied the $0.51 \%$ correction described by Sapart et al. (2012) to the Northern Hemisphere data, in order to create the global composite. 
(a)

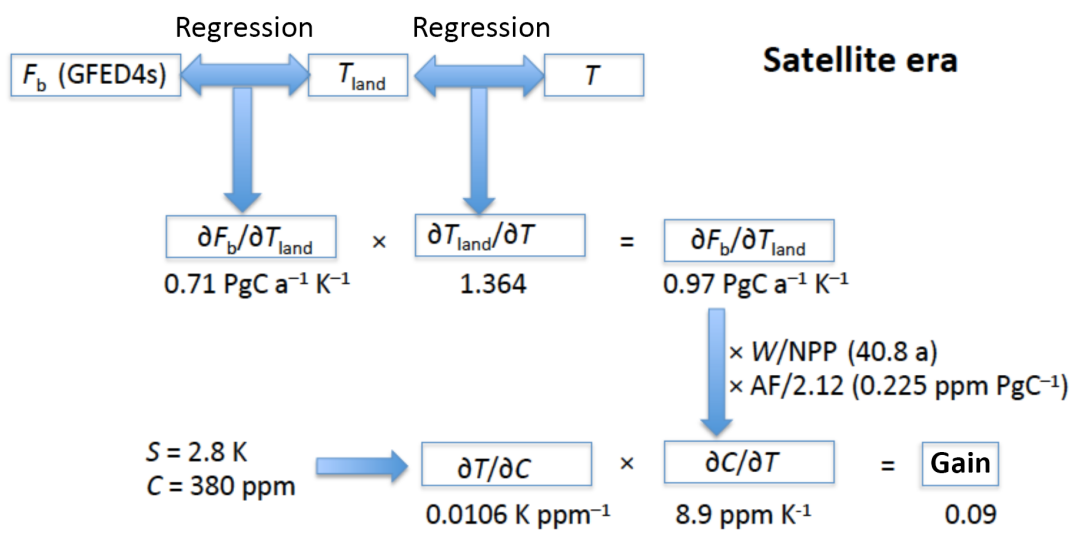

(b)

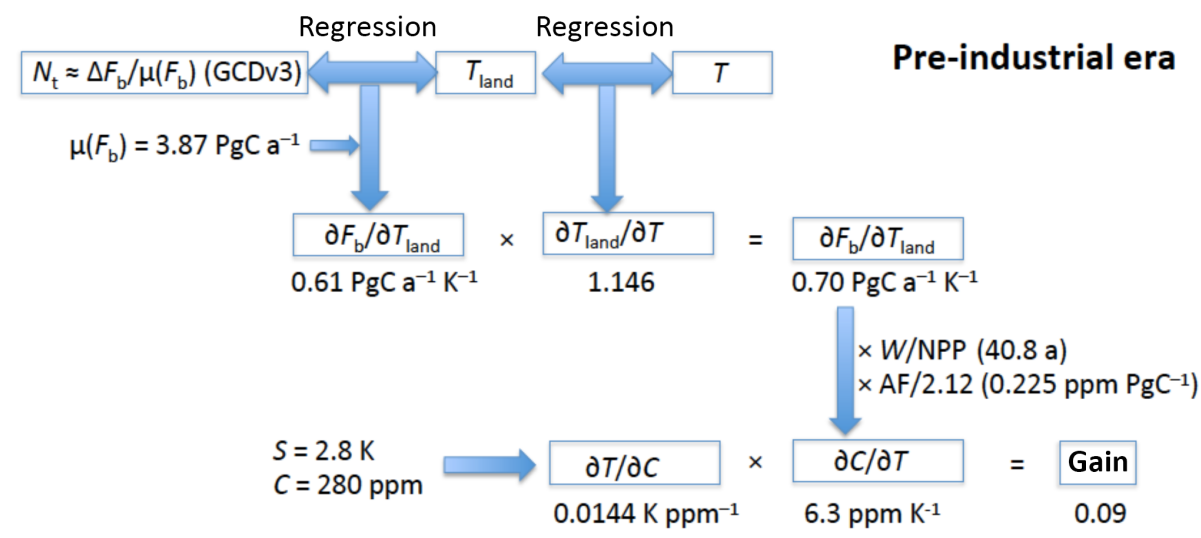

Figure 1. Schematic of the analysis of global fire-temperature relationships for the (a) satellite and (b) pre-industrial eras. $F_{\mathrm{b}}$ : biomass burning flux; $T_{\text {land }}$ : global mean land temperature; $T$ : global mean temperature; $W$ : global land carbon storage; NPP: global net primary production; $W$ / NPP: residence time of land carbon; AF: airborne fraction; 2.12: conversion factor from ppm to Pg C; $S$ : climate sensitivity; $C$ : atmospheric $\mathrm{CO}_{2}$ mole fraction; $N_{t}$ : normalized anomalies of charcoal data; $\Delta F_{\mathrm{b}}$ : biomass burning flux anomalies; $\mu\left(F_{\mathrm{b}}\right)$ : mean biomass burning flux. See text for sources of temperature data.

\subsection{Global palaeo-temperature data}

We calculated annual area-weighted averages of mean annual temperature anomalies for land grid points, using the $5^{\circ}$ gridded data set of Mann et al. (2009), which covers the interval from 500 through $2006 \mathrm{CE}$. We used a base period of 19611990 CE to calculate anomalies. We did not use the global average of the PAGES 2k Consortium (2013) because this reconstruction is dominated by records from the Arctic and Antarctic, where there are few or no fires, prior to $800 \mathrm{CE}$. Although there are many last-millennium temperature reconstructions for the Northern Hemisphere, global data sets are few and the rest cover shorter time intervals than Mann et al. (2009).

2.5 Composite curves of charcoal, $\delta^{13} \mathrm{C}$ of $\mathrm{CH}_{4}, \mathrm{CH}_{4}$, and palaeo-temperature data

The individual charcoal records have a median sampling interval of 16.75 years over the interval 1-100 CE (with 250 sites contributing data), and 16.90 years over the interval 1601-1700 CE (350 sites), for a typical sample density of over 1000 per century. The $\delta^{13} \mathrm{C}$ of $\mathrm{CH}_{4}$ and $\mathrm{CH}_{4}$ records average 2.5 and 3.0 samples per century over the interval $1-$ $500 \mathrm{CE}$, increasing to 10 per century over the interval 1601$1700 \mathrm{CE}$. The temperature data have annual resolution. Consequently, for the regression analyses we developed composite (across sites, in the case of charcoal) or smoothed curves (for the other variables) with a common sampling interval, and an appropriate smoothing window for each series. We used the R package locfit (R Core Team, 2016; Loader, 2013) to fit these curves.

Data smoothing can induce spurious cross-correlations between series (Loader, 1999; Granger and Newbold, 1986), while using an overly high-resolution sampling interval can create temporal pseudoreplication, whereby sequential observations do not provide independent information (Hurlbert, 1984). Both could inflate the apparent significance of relationships among series. We chose the sampling interval 
and smoothing window by examining diagnostic checks of the regression analyses of charcoal (as the response variable) with temperature, or $\delta^{13} \mathrm{C}$ of $\mathrm{CH}_{4}$ and $\mathrm{CH}_{4}$ (as predictors), attempting to minimize the autocorrelation of the residuals as a guard against pseudoreplication. This process led to the selection of a 50-year time step for the evaluation of the smoothed curves. For the charcoal and temperature data, we selected a 50-year (half-width) fixed smoothing window, which suppresses inter-annual to decadal-scale variability in those series, while preserving longer-term variations. The $\delta^{13} \mathrm{C}$ of $\mathrm{CH}_{4}$ and $\mathrm{CH}_{4}$ data are too sparse in the first part of the record to use a fixed-width smoothing window, and so we used the variable window width or "span" approach with the span parameter equal to 0.1 . This strategy led to some interpolation in the sparser parts of these records. We obtained bootstrap confidence intervals for the smoothed curves. For charcoal, we used the "bootstrap-by-site" approach described by Blarquez et al. (2014), which allows the impact of the variations in the spatial distribution of the charcoal records to be assessed, and the standard approach for the other series. The $\mathrm{R}$ code used to produce the composite/smoothed curves is included in the Supplement (Sects. 2-5).

\subsection{Comparison of charcoal and methane records}

The isotopic composition of atmospheric $\mathrm{CH}_{4}$ depends on the magnitudes and isotopic discrimination factors of different contributors to the global $\mathrm{CH}_{4}$ budget. Thus, although variations in biomass burning emission of $\mathrm{CH}_{4}$ are expected to influence its isotopic composition, there is no direct correspondence between isotopic composition and the biomass burning flux. The isotopic composition of $\mathrm{CH}_{4}$ can also be influenced by changes in the magnitude and/or isotopic discrimination of other methane fluxes, of which the microbial source (methanogenesis in wetlands and wet soils and in other anoxic environments including ruminant stomachs) dominates. Moreover, isotopic discrimination by methanogenesis shows large geographic variations and cannot be assumed to be the same now (with widespread agricultural grazing and draining of natural wetlands) as it was in preindustrial times. We therefore chose to compare the $\mathrm{CH}_{4}$ isotopic record with the charcoal record by treating the isotopic discrimination factors as unknown and using a regression approach (Fig. 1), respecting the isotopic mass balance, to test whether the two types of record are systematically related to one another. After $1700 \mathrm{CE}$, the relationships between charcoal and temperature and between charcoal and $\delta^{13} \mathrm{C}\left[\mathrm{CH}_{4}\right]$ and $\left[\mathrm{CH}_{4}\right]$ become significantly distorted. Regressions were therefore fitted using composite/smoothed curve data only up to and including $1700 \mathrm{CE}$.

The mass balance equation for the principal (non-fossil fuel) annual $\mathrm{CH}_{4}$ fluxes to the atmosphere is

$F=F_{\mathrm{m}}+F_{\mathrm{g}}+F_{\mathrm{b}}$, where $F$ is the total flux, $F_{\mathrm{m}}$ is the microbial flux, $F_{\mathrm{g}}$ is the geological flux (natural seepage from underground gas reservoirs), and $F_{\mathrm{b}}$ is the biomass burning flux. The isotopic mass balance equation is

$\delta=\delta_{\mathrm{m}}\left(F_{\mathrm{m}} / F\right)+\delta_{\mathrm{g}}\left(F_{\mathrm{g}} / F\right)+\delta_{\mathrm{b}}\left(F_{\mathrm{b}} / F\right)-\varepsilon$,

where $\delta$ is the isotopic signature $\left(\delta^{13} \mathrm{C}\right)$ of global atmospheric $\mathrm{CH}_{4}, \delta_{\mathrm{m}}, \delta_{\mathrm{g}}$, and $\delta_{\mathrm{b}}$ are the isotopic signatures of the microbial, geological, and biomass burning sources respectively and $\varepsilon$ is the isotopic discrimination of $\mathrm{CH}_{4}$ oxidation in the atmosphere and soils. Rearrangement of Eqs. (2) and (3) yields

$$
\begin{aligned}
F_{\mathrm{b}} & =F\left(\delta-\delta_{\mathrm{m}}+\varepsilon\right) /\left(\delta_{\mathrm{b}}-\delta_{\mathrm{m}}\right) \\
& -F_{\mathrm{g}}\left(\delta_{\mathrm{g}}-\delta_{\mathrm{m}}\right) /\left(\delta_{\mathrm{b}}-\delta_{\mathrm{m}}\right) .
\end{aligned}
$$

The total flux $F$ is related to the global $\mathrm{CH}_{4}$ concentration $M$ in steady state by $F=f M / \tau$, where $f$ is the conversion factor between atmospheric concentration and mass and $\tau$ is the atmospheric lifetime of $\mathrm{CH}_{4}$, which we assume to be constant. The geological flux can also be assumed to be constant, although its magnitude is disputed (Schwietzke et al., 2016; Petrenko et al., 2017). The steady-state assumption is appropriate because we are considering variations over periods longer than the atmospheric lifetime of $\mathrm{CH}_{4}$, approximately 9 years (Schwietzke et al., 2016). Equation (4) can then be resolved into the sum of three components: a constant intercept, a component proportional to $M$, and a component proportional to the product $\delta M$. Equation (4) also holds, with appropriate adjustment of units, if the $F_{\mathrm{b}}$ is expressed in normans (normalized anomalies); then all of the fluxes are relative to the mean value of $F_{\mathrm{b}}$. We used ordinary linear regression of charcoal normans with $M$ and $\delta M$ as predictors to quantify the relationship between the charcoal data and $\mathrm{CH}_{4}$ isotopic composition. The inclusion of $\mathrm{CH}_{4}$ concentration in this analysis is essential, because variations in $\delta$ could be brought about irrespective of biomass burning by variations in $F_{\mathrm{m}}$, which is generally much larger than $F_{\mathrm{b}}$.

\subsection{Calculation of feedback strengths and gain}

The global relationship between biomass burning $\mathrm{CO}_{2}$ emissions and temperature provides an estimate of the strength of the feedback. We define feedback strength as the equilibrium sensitivity of atmospheric $\mathrm{CO}_{2}$ to global land temperature in $\mathrm{ppm} \mathrm{K}^{-1}$. This can be further converted to gain (Lashof et al., 1997). Following the convention established by Hansen et al. (1984), gain (g) is the product of the feedback strength and the climate sensitivity (i.e. the global mean surface temperature change for a doubling of $\mathrm{CO}_{2}$ concentration) expressed in $\mathrm{K} \mathrm{ppm}^{-1}$. Then the temperature amplification $\Delta T / \Delta T_{0}$, where $\Delta T$ is the actual temperature change and $\Delta T_{0}$ is the reference temperature change without the feedback, is

$\Delta T / \Delta T_{0}=1 /(1-\mathrm{g})$. 


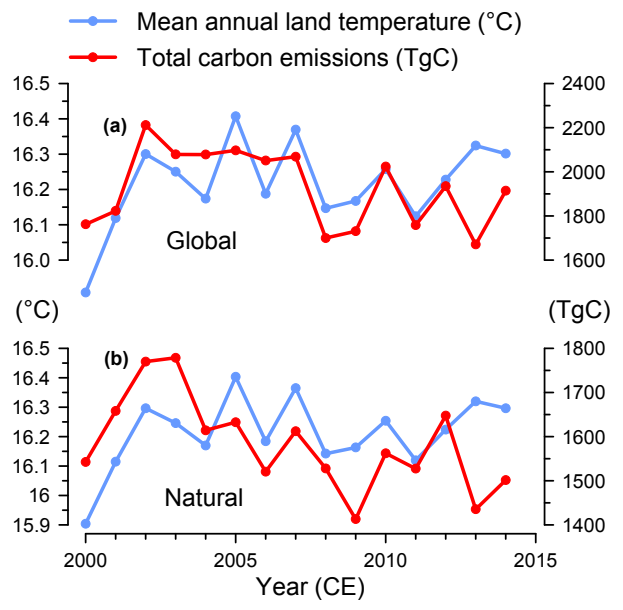

Figure 2. Co-evolution of temperature and fire-related emissions over the period between 2000 and 2014. The temperature data are from the NOAA data set (NOAAGlobalTemp v4.0.1; doi10.7289/V5FN144H; Vose et al., 2012) and the emissions data are from GFED4 (Randerson et al., 2015, www.globalfiredata.org, last access: 16 February 2018). The top panel (a) shows global temperature (in blue) and emissions (in red) after excluding agricultural areas; the bottom panel (b) shows temperature (in blue) and emissions (in red) from areas of natural vegetation only, excluding both deforestation fires and peatland fires.

Note that this convention (Hansen et al., 1984) is widely applied in the literature on terrestrial biogeochemical feedbacks. However, an alternative convention exists in which the quantity defined in Eq. (5) is called the gain, while the quantity we call gain is called the feedback factor (see, e.g., Roe, 2009).

The equilibrium sensitivity of atmospheric $\mathrm{CO}_{2}$ concentration to a change in the biomass burning flux was estimated using a box model, with parameters derived from either present-day or palaeo-relationships. The principle is that an increased rate of removal of land carbon due to fire results in a reduced steady-state carbon storage and a correspondingly increased atmospheric $\mathrm{CO}_{2}$ content. The change in atmospheric $\mathrm{CO}_{2}$ concentration is given to a good approximation by

$\Delta \mathrm{C} \approx(W / \mathrm{NPP}) \Delta F_{\mathrm{b}} \mathrm{AF} / 2.12$

where $\Delta \mathrm{C}$ is the change in atmospheric $\mathrm{CO}_{2}$ concentration (ppm), $W$ is total land ecosystem carbon storage (Pg C), NPP is total land net primary production $\left(\mathrm{PgC} \mathrm{a}^{-1}\right), \Delta F_{\mathrm{b}}$ is the change in biomass burning carbon flux $\left(\mathrm{PgCa}^{-1}\right), \mathrm{AF}$ is the airborne fraction (the fraction of emitted $\mathrm{CO}_{2}$ remaining in the atmosphere), and the factor 2.12 converts $\mathrm{PgC}$ to $\mathrm{ppm}$ (http://cdiac.ornl.gov/pns/convert.html, last access: 16 February 2018; Ciais et al., 2014). (The full derivation of Eq. (6) is given in the Appendix.) For the satellite era, we related $\Delta F_{\mathrm{b}}\left(\mathrm{Pg} \mathrm{Ca}^{-1}\right)$ statistically to temperature data. For the pre-industrial era, we related normalized charcoal

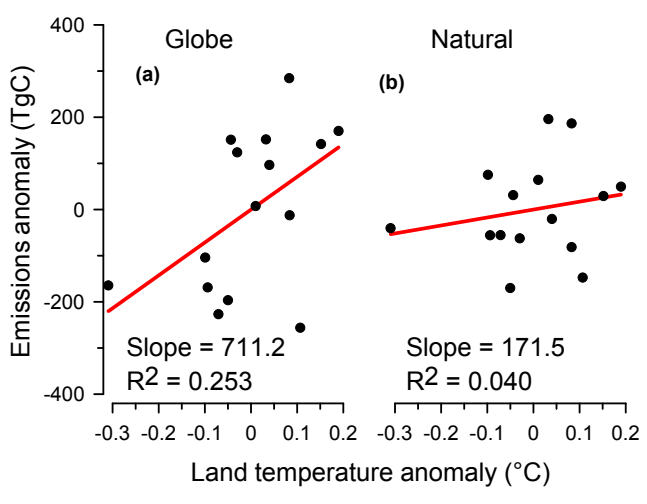

Figure 3. Relationship between global fire-related emissions and temperature over the period between 2000 and 2014. Panel (a) shows the relationship between global temperature and emissions after excluding agricultural areas; panel (b) shows the relationship between temperature and emissions from areas of natural vegetation only, excluding both deforestation fires and peatland fires.

anomalies (dimensionless) statistically to temperature data and multiplied them by an estimate of the long-term mean $F_{\mathrm{b}}$ for the period up to $1600 \mathrm{CE}\left(3.87 \mathrm{PgC} \mathrm{a}^{-1}\right)$. This estimate was based on the calibration of the methane isotope record by Sapart et al. (2012), as follows: we multiplied the contemporary flux of $2.02 \mathrm{Pg} \mathrm{Ca}^{-1}$ (the average of five satellite-based estimates from Shi et al., 2015) by the ratio of the global biomass burning $\mathrm{CH}_{4}$ flux inferred for 1$1600 \mathrm{CE}\left(27.4 \mathrm{TgCH}_{4} \mathrm{a}^{-1}\right)$ to the same flux inferred from GFED4s (14.3 $\left.\mathrm{Tg} \mathrm{CH}_{4} \mathrm{a}^{-1}\right)$. Since feedback strength is related to timescale (Roe, 2009), we assumed an AF appropriate to the centennial timescale (Joos et al., 2013), and standard values for global net primary production and total carbon storage in vegetation, litter, and non-permafrost soils. The derivation of Eq. (6), and details of calculations including the uncertainty propagation, are provided in the Appendix.

\section{Results}

\subsection{Relationship between biomass burning flux and global average land temperature during the satellite era}

The sensitivity of the MODIS-era biomass burning flux to temperature (Fig. 2) was obtained by regression of GFED4s annual fluxes against global (annual average) land temperature data, yielding a slope of $0.71 \mathrm{Pg} \mathrm{C} \mathrm{K}^{-1}$ with a standard error of $\pm 0.34 \mathrm{PgC} \mathrm{K}^{-1}$ (Fig. 3). Although approaching statistical significance, this relationship was weak $\left(R^{2}=0.25\right.$; $p=0.058)$. The slope of the relationship, however, was shown to be insensitive to individual extreme years (see Supplement, Sect. 8). 


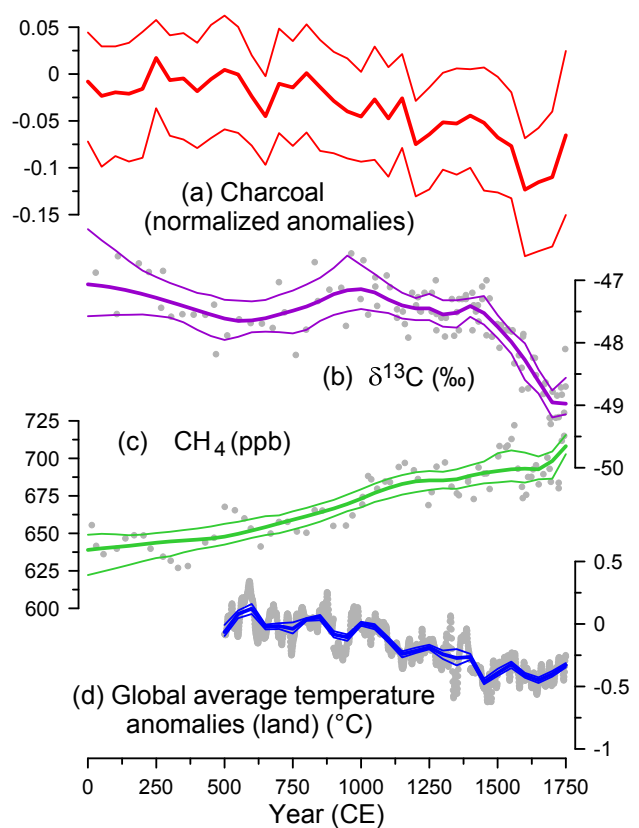

Figure 4. Indices of pre-industrial global biomass burning trends, 0-1750 CE: (a) normalized charcoal anomalies, (b) $\delta^{13} \mathrm{C}$ of $\mathrm{CH}_{4}$ (\%o) based on a composite of the data from Ferretti et al. (2005), Mischler et al. (2009), and Sapart et al. (2012), and (c) $\mathrm{CH}_{4}$ concentration (ppb) from Etheridge et al. (2010). Panel (d) shows global average temperature anomalies over land $\left({ }^{\circ} \mathrm{C}\right)$ from Mann et al. (2009). The plots show the 50-year smoothed record for each indicator, with $95 \%$ bootstrap confidence intervals; the individual data points for $\delta^{13} \mathrm{C}, \mathrm{CH}_{4}$, and land temperature are shown by grey points. There are too many individual charcoal points to be shown.

\subsection{Estimation of feedback strength during the satellite era}

The fitted relationship of annual biomass burning flux to temperature provides an estimate of the feedback strength of $6.5 \pm 3.4 \mathrm{ppm} \mathrm{K}^{-1}$ with respect to global land temperature. We took account of the greater variability of land versus global mean temperatures by means of a regression of land versus global mean temperature anomalies for 2000 2014 (Fig. 3a), yielding a slope of $1.364 \pm 0.098 \mathrm{~K} \mathrm{~K}^{-1}$. Correcting the estimated land-based feedback strength with this slope yielded a corrected feedback strength of $8.9 \pm 4.7 \mathrm{ppm} \mathrm{K}^{-1}$. Assuming a value of $S=2.8 \mathrm{~K}$, the central value for climate sensitivity recently obtained by a novel emergent-constraint method (Cox et al., 2018), led to $\partial T / \partial C=S /(C \ln 2)=0.0106 \mathrm{~K} \mathrm{ppm}^{-1}($ evaluated at $C=$ $380 \mathrm{ppm}$ ) and an estimated gain of $0.09 \pm 0.05$. (The uncertainty of the gain estimate does not include the uncertainty in $S$, which affects all estimates of gain but does not affect comparisons of gain made with the same value of $S$.)

However, if deforestation and peat fires (which account for $18-28 \%$ of emissions) were excluded from the calcula- tions (Fig. 3b), no significant relationship of biomass burning emissions to temperature remained $(p=0.476)$. Interannual variability in tropical deforestation and peatland fires is well known to be correlated with ENSO (van der Werf et al., 2010), whereas ENSO-related changes in temperature and precipitation are both positive and negative across extratropical regions - resulting in compensatory impacts on total non-anthropogenic fire emissions, which show no clear general relationship to temperature during the satellite era (Prentice et al., 2011).

\subsection{Relationship between methane and charcoal records of biomass burning}

The fitted regression equation relating charcoal normans (dimensionless) to the concentration of $\mathrm{CH}_{4}\left(M_{t}\right.$ at time $\left.t, \mathrm{ppb}\right)$ and the product of the $\delta^{13} \mathrm{C}_{\text {of }} \mathrm{CH}_{4}\left(\delta_{t}\right.$ at time $t, \%$ o) with $M_{t}$ $\left(\delta_{t} M_{t}, \% \circ \mathrm{ppb}\right)$ is

$N_{t}=0.0659+0.00118 M_{t}+0.00004679 \delta_{t} M_{t}$

$\left(R^{2}=0.771 ; F=54.04\right.$ with 1 and $\left.32 \mathrm{~d} f ; p<0.0001\right)$. The standard errors of the fitted regression coefficients in Eq. (7) are as follows: \pm 0.0147 for the intercept, $\pm 0.00070 \mathrm{ppb}^{-1}$ for the coefficient of $M_{t}$, and $\pm 0.00001237 \% o^{-1} \mathrm{ppb}^{-1}$ for the coefficient of $\delta_{t} M_{t}$ (see Supplement, Sect. 7 for more details). The Ljung-Box statistic (Ljung and Box, 1978) is 16.9 with $12 \mathrm{~d} f$ and $p=0.15$, i.e. not significant, indicating that pseudoreplication and the possibility of spurious correlation are absent.

This analysis shows, for the first time, that the charcoal and methane data sources (Fig. 4) are in good agreement (Fig. 5b). It is therefore appropriate to use charcoal normans (based on a global compilation, albeit with some unnevenness is sampling) as an indicator for normalized anomalies of global biomass burnt.

The ratio $r$ of the coefficient of $M_{t}$ to the coefficient of $\delta_{t} M_{t}$ could in principle provide an independent estimate of the microbial discrimination factor, as $\delta_{\mathrm{m}}=\varepsilon-r$ by rearrangement of Eq. (4). However, in practice this calculation does not provide a strong constraint on $\delta_{\mathrm{m}}$. Assuming $\varepsilon=-6.3 \%$ (Schwietzke et al., 2016) and with $r=25.2 \pm 16.4 \%$ from Eq. (7), $\delta_{\mathrm{m}}$ is estimated as $-31.5 \pm 16.4 \%$ o. The central estimate is small in magnitude compared to typical values around $-60 \%$ (e.g. Sapart et al., 2012), but its standard error is large.

\subsection{Relationship between charcoal records and global average land temperature}

The fractional sensitivity of the millennium-scale biomass burning flux to temperature was obtained by regression of charcoal normans against global land temperature. The fitted regression equation relating anomalies of charcoal normans and temperature (Fig. 5c) is

$N_{t}=-0.0205+0.158 T_{t}$, 

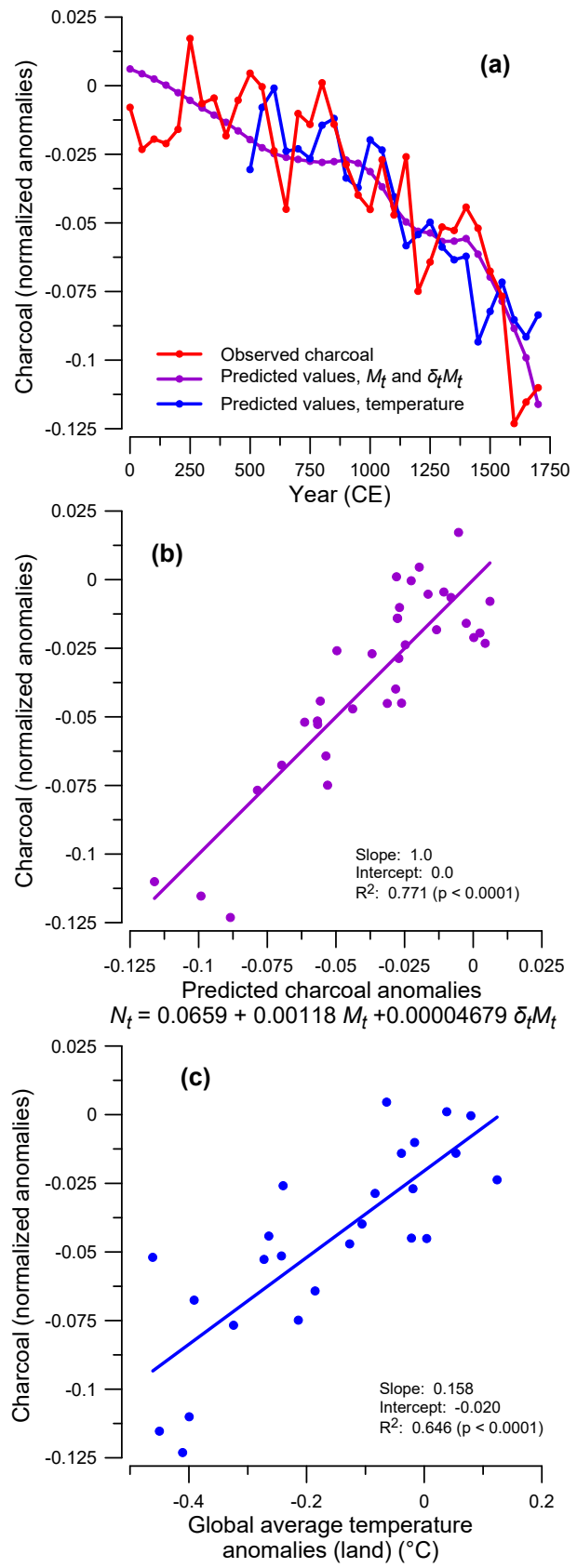

Figure 5. Relationship between normalized charcoal anomalies and global land temperature. The data points refer to 50-year binned data. The top panel (a) shows observed charcoal normans; estimated values based on the linear regression of charcoal normans against the $\delta^{13} \mathrm{C}$ of $\mathrm{CH}_{4}$ and the product of this $\delta^{13} \mathrm{C}$ value with the concentration of $\mathrm{CH}_{4}$ are plotted in (b); and estimated values based on the linear regression of charcoal normans against temperature are plotted in (c). Note that the slope and intercept of the relationship shown in panel (b) are necessarily 1.0 and 0.0 respectively - the key point is the goodness of fit shown between the two data sources after the charcoal data have been calibrated against the $\mathrm{CH}_{4}$ and $\mathrm{CH}_{4}$ isotopic records. where the $N_{t}$ is charcoal normans (dimensionless) and $T_{t}$ is the area-weighted average temperatures $\left({ }^{\circ} \mathrm{C} ; R^{2}=0.646\right.$; $F=41.98$ with 1 and $23 \mathrm{~d} f ; p<0.0001)$. The standard errors of the fitted regression coefficients in Eq. (8) are \pm 0.005 for the intercept, and $\pm 0.024 \mathrm{~K}^{-1}$ for the coefficient of $T_{t}$. The Ljung-Box statistic is 16.2 with $12 \mathrm{~d} f$ and $p=0.184$, i.e. non-significant (see Supplement, Sect. 6).

Regional analyses show that the observed strongly positive global-scale relationship between temperature and normalized charcoal anomalies is mirrored in the northern extratropics, northern tropics, and southern tropics (Fig. 6), but not in the southern extratropics. However the Mann et al. (2009) data set contains relatively few observations from the southern extratropics and shows an anomalously large temperature decline from 500 to $1500 \mathrm{CE}$ compared to other reconstructions (e.g. Neukom et al., 2014; Gergis et al., 2016; Supplement, Sect. 11). We reserve judgment as to whether this regional difference in the relationship is meaningful. In any case, the land area represented by the southern extratropics is small.

\subsection{Estimation of feedback strength during the pre-industrial era}

Applying an estimated long-term mean value $\quad F_{\mathrm{b}}=3.87 \pm 1.94 \mathrm{PgCa}^{-1} \quad$ yielded $\Delta F_{\mathrm{b}}=0.61 \pm 0.32 \mathrm{PgCa}^{-1} \mathrm{~K}^{-1}$. The resulting estimate of feedback strength is $5.6 \pm 3.2 \mathrm{ppm} \mathrm{K}^{-1}$ with respect to land temperature. A regression of land versus global mean temperatures based on the 500-1700 CE data in Mann et al. (2009) yielded a slope of $1.146 \pm 0.0018 \mathrm{~K} \mathrm{~K}^{-1}$ (Supplement Sect. 9). Correcting the estimated land-based feedback strength with this slope, and assuming $S=2.8 \mathrm{~K}$ as before, led to $\partial T / \partial C=S /(C \ln 2)=0.0144 \mathrm{~K} \mathrm{ppm}^{-1}$ (evaluated at $C=280 \mathrm{ppm})$ and an estimated gain of $0.09 \pm 0.05$. The uncertainty in this value is dominated by the large uncertainty assigned to the mean pre-industrial biomass burning flux.

\section{Discussion and conclusions}

Our analyses of data from the pre-industrial era yielded an estimate of the feedback strength of $5.6 \pm 3.2 \mathrm{ppm} \mathrm{K}^{-1}$ for land temperature and a gain of $0.09 \pm 0.05$. Our analyses for the satellite era yielded $6.5 \pm 3.4 \mathrm{ppm} \mathrm{K}^{-1}$ for land temperature and also a gain of $0.09 \pm 0.05$. The agreement between the two gain estimates is fortuitous, however. The pre-industrial estimate is founded on a strong relationship between charcoal data and reconstructed temperatures. Its uncertainty is largely due to uncertainty about the absolute magnitude of average biomass burning emissions in pre-industrial times. In contrast, the uncertainty of the satellite-era estimate is largely due to the weakness of the relationship between emissions and observed temperatures. Moreover, this relationship is dominated by the well-known correlation of anthropogenic 


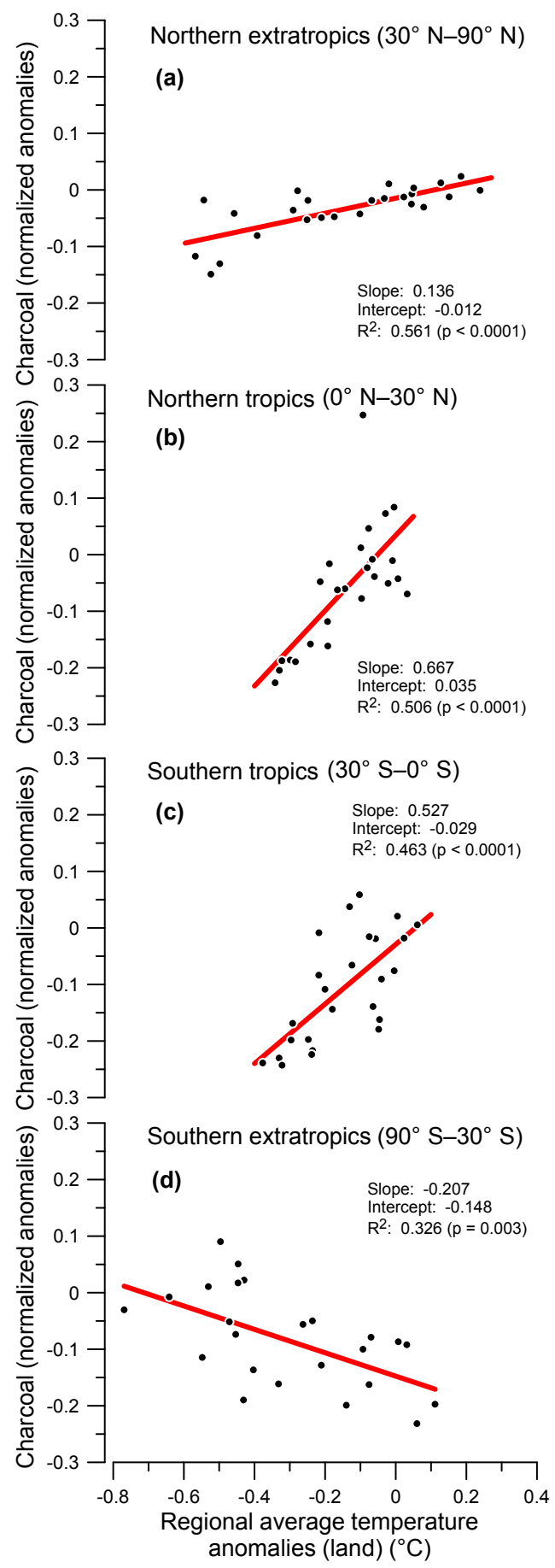

Figure 6. Relationship between normalized charcoal anomalies and land temperature for the (a) northern extratropics, (b) northern tropics, (c) southern tropics, and (d) southern extratropics. The data points refer to 50-year binned data.

burning in the tropics with the ENSO cycle. The period for which reliable satellite-based estimates of biomass burning emissions are available is too short to have allowed the ef- fects of longer-term climate variability to emerge, especially given the uncertainties associated with the large differences between different satellite products (Hantson et al., 2016).

It is unclear whether the magnitude of the fire feedback estimated on the basis of inter-annual variability should be different from the estimate obtained based on decadal to centennial variability. The palaeo-record does not provide a test of this because there are too few annually resolved charcoal records, while the satellite-era records cover too short a period to be able to examine longer-term sensitivity. However, even if the satellite-era data provided a strong constraint on fire feedback, the estimate of gain based on pre-industrial, centennial-scale climate variability would likely still be more relevant to long-term climate projections.

Many of the influences on fire have changed dramatically between pre-industrial and recent times. The geographic pattern of fire frequency shows an unambiguous decline with human population density, a relationship that holds across more than 4 orders of magnitude of population density (Bistinas et al., 2014; Knorr et al., 2014). Moreover, global biomass burning has declined precipitously since its peak in the mid-nineteenth century, as shown by both charcoal data (Marlon et al., 2008, 2016) and carbon monoxide isotopes in ice and contemporary air (Wang et al., 2010). On the other hand, tropical deforestation and burning of peat substrates yield intense, localized pyrogenic sources of $\mathrm{CO}_{2}$ that closely co-vary with inter-annual variation in the duration and intensity of the dry season (van der Werf et al., 2010). Our estimate of gain based on pre-industrial, centennial-scale climate variability is likely more relevant to long-term climate projections, but any realistic estimation of future fire risks and feedbacks must consider the pervasive effects of human settlement and land use (Knorr et al., 2014). It is also possible that the influence of temperature variability on interannual timescales might generally differ from its influence on decadal-to-millennial timescales, but we cannot establish this from currently available palaeo-data because there is too little annually resolved information, while the interval for which we have satellite data is too short even to resolve decadal variability.

Charcoal abundances have generally been interpreted as a measure of "fire activity" or relative changes in the quantity of burned biomass (e.g. Power et al., 2008; Harrison et al., 2010; Daniau et al., 2012; Marlon et al., 2016). There have been some attempts to quantify the relationship between charcoal abundance and burnt area or total biomass consumed at a local scale (see, e.g., Peters and Higuera, 2007; Duffin et al., 2016; Leys et al., 2017). These analyses, however, show a strong dependency on vegetation type and fire regime and the need to apply calibrations accounting for charcoal source area in the same way as for the interpretation of pollen abundances (Prentice, 1985: Sugita, 1994). Such calibrations have been made for Europe (Adolf et al., 2018) but not for other regions. Our analyses establish for the first time that there is a good relationship $\left(R^{2}=0.77\right)$ between 
global charcoal abundance, expressed as normalized anomalies, and the methane and methane-isotopic record from ice cores. Since emissions reflect the amount of biomass consumed by fire, which in turn is influenced by area burnt and fire intensity, these analyses support the idea that the sedimentary charcoal record - when synthesized at continental to global scales - can provide quantitative evidence for changes in the global biomass burning carbon flux. Establishing the quantitative relationship between charcoal abundance and fire emissions is key to being able to exploit the continued expansion of the spatial and temporal coverage of charcoal records (Marlon et al., 2016) to examine regional changes in fire regimes on multiple timescales.

The strength of the global land climate-carbon-cycle feedback has been assessed by Arora et al. (2013) on the basis of nine CMIP5 Earth system models. Five models that do not explicitly represent fire yield feedback strengths (after converting $\mathrm{PgC}$ to $\mathrm{ppm}$ and multiplying them by the airborne fraction) in the range 6.8 to $19.9 \mathrm{ppm} \mathrm{K}^{-1}$ with a median of $17.5 \mathrm{ppm} \mathrm{K}^{-1}$. Of four models that do represent fire, two yield values in the same range; the other two (sharing the same land model) yield lower values but have been shown to greatly underestimate the feedback based on the observed relationship between tropical land temperatures and the rate of increase in atmospheric $\mathrm{CO}_{2}$ concentration (Wenzel et al., 2014). Our global estimate of the biomass burning contribution as $5.6 \pm 3.2 \mathrm{ppm} \mathrm{K}^{-1}$, based on the pre-industrial period, suggests that the contribution of fire emissions to the climate-carbon-cycle feedback is substantial. Our estimate may even be conservative. Sapart et al. (2012) estimated the intertemporal coefficient of variation in the biomass burning $\mathrm{CH}_{4}$ flux to be $7.3 \%$ for the period 1-1600 CE, compared to only $2.9 \%$ in the charcoal anomalies.
Although some of the models in the assessment by Arora et al. (2013) included fire as an interactive process, none considered deforestation or peat fires. A substantial component of the total contemporary land climate-carbon-cycle feedback appears to be attributable to anthropogenic fires in the tropics and their spatially coherent association with ENSO variability. This is in contrast with extratropical fire regimes, which show regionally asynchronous responses to climate variability (Prentice et al., 2011), and the response of net ecosystem exchange to warming, which is asymmetrical between low and high latitudes (Wenzel et al., 2014). The importance of deforestation and peatland fires in driving fire feedback in the recent decades suggests that measures to protect tropical forests and peatlands could appreciably reduce the magnitude of the climate-carbon-cycle feedback.

The climate-carbon-cycle feedback is an important benchmark for ESMs. Despite growing interest in the environmental and human drivers and impacts of fire (Bowman et al., 2009, 2011; Harrison et al., 2010; Fischer et al., 2016), the global-scale contribution of biomass burning to the climatecarbon-cycle feedback has been poorly quantified. Our analyses provide an independent estimate of this feedback, illustrating the use of the palaeo-record to estimate Earth system quantities that may be difficult or impossible to derive from contemporary observations.

Data availability. All the data used in the analyses are public and available from the sites given in the text or references. Our analyses are fully documented in the Supplement. 
Appendix A: The box model, parameter estimates, and their uncertainties

In steady state, carbon inputs to biomass and subsequently (via litter production) to soil organic matter, corresponding to net primary production (NPP), must be balanced by outputs: heterotrophic respiration, $R_{\mathrm{H}}$, and biomass burning, $F_{\mathrm{b}}$. Here we designate rates of carbon transfer by heterotrophic respiration and biomass burning respectively as $k_{\mathrm{r}}$ and $k_{\mathrm{b}}$, such that $k_{\mathrm{b}}=F_{\mathrm{b}} / W$; $k_{\mathrm{b}}^{*}=F_{\mathrm{b}}^{*} / W^{*}$ (where the asterisk denotes new steady-state values after a change in the burning rate); then $k_{\mathrm{r}}=$ $k_{\mathrm{r}}^{*}=R_{\mathrm{H}} / W=\left(\mathrm{NPP}-F_{\mathrm{b}}\right) / W=\left(\mathrm{NPP}-F_{\mathrm{b}}^{*}\right) / W^{*}$, assuming that the impact of an altered fire frequency on NPP is small compared to its effect on $W$ (Martin Calvo and Prentice, 2015). Hence, $W^{*} / W=\left(\mathrm{NPP}-F_{\mathrm{b}}^{*}\right) /\left(\mathrm{NPP}-F_{\mathrm{b}}\right)$ and upon rearrangement

$\Delta W=-W \cdot \Delta F_{\mathrm{b}} /\left(\mathrm{NPP}-F_{\mathrm{b}}\right)$,

where $\Delta W=W^{*}-W$ and $\Delta F_{\mathrm{b}}=F_{\mathrm{b}}^{*}-F_{\mathrm{b}}$ or, to a close approximation (given $F_{\mathrm{b}} \ll \mathrm{NPP}$ ),

$\Delta W \approx-W . \Delta F_{\mathrm{b}} / \mathrm{NPP}$.

This calculation is insensitive to $\mathrm{CO}_{2}$ effects on NPP, as an increase in NPP in steady state implies a proportionate increase in $W$.

Global terrestrial biosphere $\mathrm{C}$ is given by Ciais et al. (2014) as the sum of $450-650 \mathrm{PgC}$ (vegetation C) and 1500-2400 (soil C), i.e. $550 \pm 100 \mathrm{Pg} \mathrm{C}$ and $1950 \pm 450 \mathrm{Pg} \mathrm{C}$ respectively - yielding a combined uncertainty of $\pm 461 \mathrm{Pg} \mathrm{C}$ $(18.4 \%)$ For global NPP, the two bottom-up estimates given by Prentice et al. (2001) are 59.9 and $62.6 \mathrm{Pg} \mathrm{Ca}^{-1}$, yielding a mean of 61.25 and a standard error $(n=2)$ of $\pm 1.35 \mathrm{Pg} \mathrm{Ca}^{-1}(2.2 \%)$. We therefore assigned values of $W=2500 \pm 461 \mathrm{PgC}$ and $\mathrm{NPP}=61.25 \pm 1.35 \mathrm{Pg} \mathrm{Ca}^{-1}$.
For contemporary biomass burning $\mathrm{C}$ emissions (Shi et al., 2015; Table 3), five satellite-derived estimates together provide a global mean of $7391.7 \mathrm{Tg} \mathrm{CO}_{2} \mathrm{a}^{-1}\left(2.02 \mathrm{Pg} \mathrm{Ca}^{-1}\right)$ with a standard deviation $(n=5)$ of $\pm 1291.2 \mathrm{Tg} \mathrm{CO}_{2} \mathrm{a}^{-1}$, corresponding to a standard error of $\pm 0.157 \mathrm{Pg} \mathrm{Ca}^{-1}$ $(7.8 \%)$. We therefore assigned $F_{\mathrm{b}}=2.02 \pm 0.157 \mathrm{PgCa}^{-1}$ for the satellite era. For the pre-industrial era, we estimated the long-term mean biomass burning $\mathrm{C}$ flux as the product of the contemporary flux of $2.02 \mathrm{Pg} \mathrm{Ca}^{-1}$ (Shi et al., 2015 ) with the ratio of the global biomass burning $\mathrm{CH}_{4}$ flux inferred from methane isotope data for the period 1$1600 \mathrm{CE}$ (27.4 $\mathrm{TgCH}_{4} \mathrm{a}^{-1}$ ) to the same flux inferred from GFED4s (14.3 $\mathrm{Tg} \mathrm{CH}_{4} \mathrm{a}^{-1}$ ) by Sapart et al. (2012), yielding $F_{\mathrm{b}}=3.87 \mathrm{Pg} \mathrm{Ca}^{-1}$. However, while Sapart et al. (2012) assigned an uncertainty of only $\pm 2.8 \mathrm{Tg} \mathrm{CH}_{4} \mathrm{a}^{-1}(10 \%)$ to their estimate of global biomass burning $\mathrm{CH}_{4}$ flux, we inflated the uncertainty of our estimate of $F_{\mathrm{b}}$ to $\pm 1.94 \mathrm{Pg} \mathrm{Ca}^{-1}$ $(50 \%)$ in order to include additional potential sources of error, which include variability of the isotopic fractionation factors and of the emission factor for $\mathrm{CH}_{4}$ with respect to $\mathrm{CO}_{2}$.

For the centennial-scale airborne fraction (AF in Eq. 6) we adopted the estimate of $0.476 \pm 0.057(12.0 \%)$ obtained by Joos et al. (2013). This estimate was derived from multiple models performing identical pulse-response experiments. The mean value here is the multi-model mean (converted from units of years to fractions by dividing by the timescale), and the uncertainties are 1 standard deviation of the variation among models. The mean value is close to the empirical estimate of 0.44 given by Ciais et al. (2014).

Conversion of the feedback strength $(\partial C / \partial T)$ into a gain requires a further assumption about the climate sensitivity $(S)$, defined as the equilibrium change in global mean temperature for a doubling of atmospheric $\mathrm{CO}_{2}$. We have used $S=2.8 \mathrm{~K}$, the central estimate provided by Cox et al. (2018). 


\section{The Supplement related to this article is available online at https://doi.org/10.5194/esd-9-663-2018-supplement.}

Author contributions. SPH, ICP, PJB, and SK designed and performed the analyses. SPH and ICP wrote the first draft of the manuscript and all authors contributed to the final version.

Competing interests. The authors declare that they have no conflict of interest.

Acknowledgements. This work was inspired by discussions at workshops of the Global Palaeofire Working Group in 2012 and 2013 and partially funded by the University of Reading. Sandy P. Harrison acknowledges the support from the ERC-funded project GC2.0 (Global Change 2.0: Unlocking the past for a clearer future, grant number 694481). This research is a contribution to the AXA Chair Programme in Biosphere and Climate Impacts and the Imperial College initiative on Grand Challenges in Ecosystems and the Environment (ICP). Patrick J. Bartlein acknowledges funding from the US National Science Foundation Geography and Spatial Science Program (1435744). We thank Sam Rabin for his review of the manuscript.

Edited by: Somnath Baidya Roy

Reviewed by: Sam Rabin and four anonymous referees

\section{References}

Adolf, C., Wunderle, S., Colombaroli, D., Weber, H., Gobet, E., Heiri, O., van Leeuwen, J. F. N., Bigler, C., Connor, S. E., Gałka, M., La Mantia, T., Makhortykh, S., Svitavska-Svobodova, H., Vannière, B., and Tinner, W.: The sedimentary and remotesensing reflection of biomass burning in Europe, Global Ecol. Biogeog., 27, 199-212, https://doi.org/10.1111/geb.12682, 2018.

Andela, N., Morton, D. C., Giglio, L., Chen, Y., van der Werf, G. R., Kasibhatla, P. S., DeFries, R. S., Collatz, G. J., Hantson, S., Kloster, S., Bachelet, D., Forrest, M., Lasslop, G., Li, F., Mangeon, S., Melton, J. R., Yue, C., and Randerson, J. T.: A humandriven decline in global burned area, Science, 356, 1356-1362, https://doi.org/10.1126/science.aal4108, 2017.

Andreae, M. O. and Merlet, P.: Emission of trace gases and aerosols from biomass burning, Glob. Biogeochem. Cycl., 15, 955-966, https://doi.org/10.1029/2000GB001382, 2001.

Arneth, A. Harrison, S. P., Zaehle, S., Tsigaridis, K., Menon, S., Bartlein, P. J., Feichter, H., Korhola, A., Kulmala, M., O'Donnell, D., Schurgers, S., Sorvari, S., and Vesala, T.: Terrestrial biogeochemical feedbacks in the climate system, Nat. Geosci., 3, 525-532, https://doi.org/10.1038/ngeo905, 2010.

Arora, V. K, Boer, G. J., Friedlingstein, P., Eby, M., Jones, C. D., Christian, J. R., Bonan, G., Bopp, L., Brovkin, V., Cadule, P., Hajima, T., Ilyina, T., Lindsay, K., Tjiputra, J. F., and Wu, T.: Carbon-concentration and carbon-climate feedbacks in CMIP5 Earth System Models, J. Climate, 26, 5289-5314, https://doi.org/10.1175/JCLI-D-12-00494.1, 2013.
Ballantyne, A., Smith, W., Anderegg, W., Kauppi, P., Sarmiento, J., Tans, P., Shevliakova, E., Pan, Y., Poulter, B., Anav, A., Friedlingstein, P., Houghton, R., and Running, S.: Accelerating net terrestrial carbon uptake during the warming hiatus due to reduced respiration, Nat. Clim. Change, 7, 148-152, https://doi.org/10.1038/nclimate3204, 2017.

Barker, J. F. and Fritz, P.: Carbon isotope fractionation during microbial methane oxidation, Nature, 293, 289-291, https://doi.org/10.1038/293289a0, 1981.

Bistinas, I., Harrison, S. P., Prentice, I. C., and Pereira, J. M. C.: Causal relationships versus emergent patterns in the global controls of fire frequency, Biogeosciences, 11, 5087-5101, https://doi.org/10.5194/bg-11-5087-2014, 2014.

Blarquez, O., Vanniere, B. , Marlon, J. R., Daniau, A-L., Power, M. J., Brewer, S., and Bartlein, P. J.: paleofire: An R package to analyse sedimentary charcoal records from the Global Charcoal Database to reconstruct past biomass burning, Comp. Geosci., 72, 255-261, https://doi.org/10.1016/j.cageo.2014.07.020, 2014.

Boucher, O., Randall, D., Artaxo, P., Bretherton, C., Feingold, G., Forster, P., Kerminen, V.-M., Kondo, Y., Liao, H., Lohmann, U., Rasch, P., Satheesh, S. K., Sherwood, S., Stevens B., and Zhang, X. Y.: Climate and aerosols. In: Climate Change 2013: The Physical Science Basis. Contribution of Working Group I to the Fifth Assessment Report of the Intergovernmental Panel on Climate Change, edited by: Stocker, T. F., Qin, D., Plattner, G.-K., Tignor, M., Allen, S. K., Boschung, J., Nauels, A., Xia, Y., Bex, V., and Midgley, P. M., Cambridge University Press, Cambridge, UK and New York, NY, USA, 2013.

Bowman, D. M. J. S., Balch, J. K., Artaxo, P., Bond, W. J., Cochrane, M. A., D’Antonia, C. M., DeFries, R. S., Doyle, J. C., Harrison, S. P., Johnston, F. H., Keeley, J. E., Krawchuk, M. A., Kull, C. A., Marston, J. B., Moritz, M. A., Prentice, I. C., Roos, C. I., Scott, A. C., Swetnam, T. W., van der Werf, G. R., and Pyne, S. J.,: Fire in the earth system, Science, 324, 481-484, https://doi.org/10.1126/science.1163886, 2009.

Bowman D. M. J. S., Balch, J., Artaxo, P., Bond, W. J., Cochrane, M. A., D’Antonio, C. M, DeFries, R., Johnston, F. H., Keeley, J. E., Krawchuk, M. A. Kull, C. A., Mack, M., Moritz, M. A., Pyne, S., Roos, C. I., Scott, A. C., Sodhi, N. S., Swetnam, T. W., and Whittaker, R.: The human dimension of fire regimes on Earth, J. Biogeog., 38, 2223-2236, https://doi.org/10.1111/j.1365-2699.2011.02595.x, 2011.

Carslaw, K. S., Lee, L. A., Reddington, C. L., Pringle, K. J., Rap, A., Forster, P. M., Mann, G. W., Spracklen, D. V., Woodhouse, M. T., Regayre, L. A., and Pierce, J. R.: Large contribution of natural aerosols to uncertainty in indirect forcing, Nature, 503, 67-74, https://doi.org/10.1038/nature12674, 2013.

Ciais, P., Sabine, C., Bala, G., Bopp, L., Brovkin, V., Canadell, J., Chhabra, A., DeFries, R., Galloway, J., Heimann, M., Jones, C., Le Quéré, C., Myneni, R. B., Piao, S., and Thornton, P.: Carbon and other biogeochemical cycles. In: Climate Change 2013: The Physical Science Basis, Contribution of Working Group I to the Fifth Assessment Report of the Intergovernmental Panel on Climate Change, edited by: Stocker, T. F., Qin, D., Plattner, G.-K., Tignor, M., Allen, S. K., Boschung, J., Nauels, A., Xia, Y., Bex, V., and Midgley, P. M., Cambridge University Press, Cambridge, UK and New York, USA, 2013.

Cox, P. M., Huntingford, C., and Williamson, M. S.: Emergent constraint on equilibrium climate sensitivity from 
global temperature variability, Nature, 553, 319-322, https://doi.org/10.1038/nature25450, 2018.

Cox, P. M., Pearson, D., Booth, B. B., Friedlingstein, P., Huntingford, C., Jones, C. D., and Luke, C. M.: Sensitivity of tropical carbon to climate change constrained by carbon dioxide variability, Nature, 494, 341-344, https://doi.org/10.1038/nature11882, 2013.

Daniau, A.-L., Bartlein, P. J., Harrison, S. P., Prentice, I. C., Brewer, S., Friedlingstein, P., Harrison-Prentice, T. I., Inoue, J., Marlon, J. R., Mooney, S., Power, M. J., Stevenson, J., Tinner, W., Andrič, M., Atanassova, J., Behling, H., Black, M., Blarquez, O., Brown, K. J., Carcaillet, C., Colhoun, E., Colombaroli, D., Davis, B. A. S., D'Costa, D., Dodson, J., Dupont, L., Eshetu, Z., Gavin, D. G., Genries, A., Gebru, T., Haberle, S., Hallett, D. J., Horn, S., Hope, G., Katamura, F., Kennedy, L., Kershaw, P., Krivonogov, S., Long, C., Magri, D., Marinova, E., McKenzie, G. M., Moreno, P. I., Moss, P., Neumann, F. H., Norström, E., Paitre, C., Rius, D., Roberts, N., Robinson, G., Sasaki, N., Scott, L., Takahara, H., Terwilliger, V., Thevenon, F., Turner, R. B., Valsecchi, V. G., Vannière, B., Walsh, M., Williams, N., and Zhang, Y.: Predictability of biomass burning in response to climate changes, Glob. Biogeochem. Cyc., 26, https://doi.org/10.1029/2011GB004249, 2012.

Duffin, K. I., Gillson, L., and Willis, K. J.: Testing the sensitivity of charcoal as an indicator of fire events in savanna environments: quantitative predictions of fire proximity, area and intensity, The Holocene, 18, 279-291, https://doi.org/10.1177/0959683607086766, 2008.

Etheridge, D. M. et al.: Law Dome Ice Core 2000-Year $\mathrm{CO}_{2}, \mathrm{CH}_{4}$, and $\mathrm{N}_{2} \mathrm{O}$ Data,IGBP PAGES/World Data Center for Paleoclimatology, Data Contribution Series \# 2010-070, NOAA/NCDC Paleoclimatology Program, Boulder CO, USA, available at: ftp://ftp.ncdc.noaa.gov/pub/data/paleo/icecore/antarctica/law/ law2006.xls), (last access: 16 February 2018), 2010.

Ferretti, D. F., Miller, J. B., White, J. W. C., Etheridge, D. M., Lassey, K. R., Lowe, D. C., MacFarling Meure, C. M., Dreier, M. F., Trudinger, C. M., van Ommen, T. D., and Langenfelds, R. L.: Unexpected changes to the global methane budget over the past 2000 years, Science, 309, 1714-1717, https://doi.org/10.1126/science.1115193, 2005.

Fischer, A. P., Spies, T. A., Steelman, T. A., Moseley, C., Johnson, B. R., Bailey, J. D., Ager, A. A., Bourgeron, P., Charnley, S., Collins, B. M., Kline, J. D., Leahy, J. E., Littell, J. S., Millington, J. D. A., Nielsen-Pincus, M., Olsen, C. S., Paveglio, T. B., Roos, C. I., Steen-Adams, M. M., Stevens, F. R., Vukomanovic, J., White, E. M., and Bowman, D. M.: Wildfire risk as a socioecological pathology, Front. Ecol. Environ., 14, 276-284, https://doi.org/10.1002/fee.1283, 2016.

Gergis, J., Neukom, R., Gallant, A. J., and Karoly, D. J.: Australasian temperature reconstructions spanning the Last Millennium, J. Climate, 29, 5365-5392, https://doi.org/10.1175/JCLID-13-00781.1, 2016.

Giglio, L., Randerson, J. T., and van der Werf, G. R.: Analysis of daily, monthly, and annual burned area using the fourthgeneration global fire emissions database (GFED4), J. Geophys. Res-Biogeo., 118, 317-328, https://doi.org/10.1002/jgrg.20042, 2013

Granger, C. W. J. and Newbold, P.: Forecasting Economic Time Series, Academic Press, 2nd edition, 1986.
Hansen, J., Lacis, A., Rind, D., Russell, G., Stone, P., Fung, I., Ruedy, R., and Lerner, J.: Climate sensitivity: Analysis of feedback mechanisms, in: Climate Processes and Climate Sensitivity, edited by: Hansen, J. E. and Takahashi, T., AGU Geophysical Monograph 29, Maurice Ewing, Vol. 5. American Geophysical Union, 130-163, 1984.

Hantson, S., Arneth, A., Harrison, S. P., Kelley, D. I., Prentice, I. C., Rabin, S. S., Archibald, S., Mouillot, F., Arnold, S. R., Artaxo, P., Bachelet, D., Ciais, P., Forrest, M., Friedlingstein, P., Hickler, T., Kaplan, J. O., Kloster, S., Knorr, W., Lasslop, G., Li, F., Mangeon, S., Melton, J. R., Meyn, A., Sitch, S., Spessa, A., van der Werf, G. R., Voulgarakis, A., and Yue, C.: The status and challenge of global fire modelling, Biogeosciences, 13, 3359-3375, https://doi.org/10.5194/bg-13-3359-2016, 2016.

Harrison, S. P., Marlon, J., and Bartlein, P. J.: Fire in the Earth System, edited by: Dodson, J., Changing Climates, Earth Systems and Society, Springer-Verlag, 21-48, https://doi.org/10.1007/978-90-481-8716-4_3, 2010.

Held, I. M. and Soden, B. J.: Robust responses of the hydrological cycle to global warming, J. Climate, 19, 5686-5699, https://doi.org/10.1175/JCLI3990.1, 2006.

Hurlbert, S. H.: Pseudoreplication and the design of ecological field experiments, Ecological Monographs, 54, 187-211, https://doi.org/10.2307/1942661, 1984.

Joos, F., Roth, R., Fuglestvedt, J. S., Peters, G. P., Enting, I. G., von Bloh, W., Brovkin, V., Burke, E. J., Eby, M., Edwards, N. R., Friedrich, T., Frölicher, T. L., Halloran, P. R., Holden, P. B., Jones, C., Kleinen, T., Mackenzie, F. T., Matsumoto, K., Meinshausen, M., Plattner, G.-K., Reisinger, A., Segschneider, J., Shaffer, G., Steinacher, M., Strassmann, K., Tanaka, K., Timmermann, A., and Weaver, A. J.: Carbon dioxide and climate impulse response functions for the computation of greenhouse gas metrics: a multi-model analysis, Atmos. Chem. Phys., 13, 2793 2825, https://doi.org/10.5194/acp-13-2793-2013, 2013.

Jung, M., Reichstein, M., Schwalm, C. R., Huntingford, C., Sitch, S. Ahlström, A., Arneth, A., Cams-Valls, G., Ciais, P., Friedlingstein, P., Gans, F., Ichii, K., Jain, A. K., Kato, E., Papale, D., Poulter, B., Raduly, B., Rödenbeck, C., Tramontana, G., Viovy, N., Wang, Y.-P., Weber, U., Zaehle, S., and Zeng, N.: Compensatory water effects link yearly global land $\mathrm{CO}_{2}$ sink changes to temperature, Nature, 541, 516520, https://doi.org/10.1038/nature20780, 2017.

Keenan, T. F., Prentice, I. C., Canadell, J. G., Williams, C. A., Wang, H., Raupach, M., and Collatz, G. J.: Recent pause in the growth rate of atmospheric $\mathrm{CO}_{2}$ due to enhanced terrestrial uptake, Nature Comms., 13428, https://doi.org/10.1038/ncomms13428, 2016.

Knorr, W., Kaminski, T., Arneth, A., and Weber, U.: Impact of human population density on fire frequency at the global scale, Biogeosciences, 11, 1085-1102, https://doi.org/10.5194/bg-111085-2014, 2014.

Krawchuk, M., Moritz, M., Parisien, M.-A., Van Dorn, J., and Hayhoe, K.: Global pyrogeography: The current and future distribution of wildfire, PLoS ONE, 4, e5102, https://doi.org/10.1371/journal.pone.0005102, 2009.

Lashof, D. A., DeAngelo, B. J., Saleska, S. R., and Harte, J.: Terrestrial ecosystem feedbacks to global climate change, Annu. Rev. Energy Environ, 22, 75-118, https://doi.org/10.1146/annurev.energy.22.1.75, 1997. 
Lee, L. A., Reddington, C. L., and Carslaw, K. S.: On the relationship between aerosol model uncertainty and radiative forcing uncertainty, PNAS, 113, 5820-5827, https://doi.org/10.1073/pnas.1507050113, 2016.

Leys, B. A., Commerford, J. L., and McLauchlan, K. K.: Reconstructing grassland fire history using sedimentary charcoal: Considering count, size and shape, PLOS ONE, 12, e0176445, https://doi.org/10.1371/journal.pone.0176445, 2017.

Li, G., Harrison, S. P., Bartlein, P. J., Izumi, K., and Prentice, I. C., Precipitation scaling with temperature in warm and cold climates: an analysis of CMIP5 simulations, Geophys. Res. Lett., 40, 4018-4024, https://doi.org/10.1002/grl.50730, 2013.

Ljung, G. and Box, G. E. P.: On a measure of lack of fit in time series models, Biometrics, 65, 297-303, https://doi.org/10.1093/biomet/65.2.297, 1978.

Loader, C.: Local Regression and Likelihood, Springer, 1999.

Loader, C.: locfit: Local Regression, Likelihood and Density Estimation, R package version 1.5-9.1, available at: https://CRAN. R-project.org/packagelocfit, (last access: 16 February 2018), 2013.

Mann, M. E., Zhang, Z., Rutherford, S., Bradley, R. S., Hughes, M. K., Shindell, D., Ammann, C., Faluvegi, G., and Ni, F.: Global signatures and dynamical origins of the Little Ice Age and Medieval Climate Anomaly, Science, 326, 1256-1260, https://doi.org/10.1126/science.1177303, 2009.

Marlon, J., Bartlein, P. J., Carcaillet, C., Gavin, D. G., Harrison, S. P., Higuera, P. E., Joos, F., Power, M., and Prentice, I. C.: Climate and human influences on global biomass burning over the past two millennia, Nat. Geosci., 1, 697-702, https://doi.org/10.1038/ngeo313, 2008.

Marlon, J. R., Bartlein, P. J., Walsh, M. K., Harrison, S. P., Brown, K. J., Edwards, M. E., Higuera, P. E., Power, M. J., Anderson, R. S., Briles, C., Brunelle, A., Carcaillet, C., Daniels, M., Hu, F. S., Lavoie, M., Long, C., Minckley, T., Richard, P. J. H., Scott, A. C., Shafer, D. S., Tinner, W., Umbanhower, C. E. Jr., and Whitlock, C.: Wildfire responses to abrupt climate change in North America, PNAS, https://doi.org/10.1073/pnas.0808212106, 2009.

Marlon, J. R., Bartlein, P. J. Daniau, A-L., Harrison, S. P., Maezumi, S. Y., Power, M. J., Tinner, W., and Vannière, B.: Global biomass burning: a synthesis and review of Holocene paleofire records and their controls, Quat. Sci. Rev., 65, 5-25, 2013.

Marlon, J. R., Kelly, R., Daniau, A.-L., Vannière, B., Power, M. J., Bartlein, P., Higuera, P., Blarquez, O., Brewer, S., Brücher, T., Feurdean, A., Romera, G. G., Iglesias, V., Maezumi, S. Y., Magi, B., Courtney Mustaphi, C. J., and Zhihai, T.: Reconstructions of biomass burning from sediment-charcoal records to improve data-model comparisons, Biogeosciences, 13, 3225-3244, https://doi.org/10.5194/bg-13-3225-2016, 2016.

Martin Calvo, M. and Prentice, I. C.: Effects of fire and $\mathrm{CO}_{2}$ on biogeography and primary production in glacial and modern climates, New Phytol., 208, 987-994, https://doi.org/10.1111/nph.13485, 2015.

Mischler, J. A., Sowers, T. A., Alley, R. B., Battle, M., McConnell, J. R., Mitchell, L., Popp, T., Sofen, E., and Spencer, M. K.: Carbon and hydrogen isotopic composition of methane over the last 1000 years, Glob. Biogeochem. Cy., 23, GB4024, https://doi.org/10.1029/2009GB003460, 2009.

Mooney, S., Harrison, S. P., Bartlein, P. J., Daniau A.-L., Stevenson, J., Brownlie, K., Buckman, S., Cupper, M., Luly, J., Black, M.,
Colhoun, E., D’Costa, D., Dodson, J., Haberle, S., Hope, G. S., Kershaw, P., Kenyon, C., McKenzie., M., and Williams, N.: Late Quaternary fire regimes of Australasia, Quat. Sci. Rev., 30, 2846, https://doi.org/10.1016/j.quascirev.2010.10.010, 2011.

Neukom, R., Gergis, J., Karoly, D. J., Wanner, H., Curran, M., Elbert, J., González-Rouco, F., Linsley, B. K. Moy, A. D., Mundo, I., Raible, C. C., Steig, E. J., van Ommen, T., Vance, T., Villalba, R., Zinke, J., and Frank, D.: Inter-hemispheric temperature variability over the last millennium, Nat. Clim. Change, 4, 362-367, https://doi.org/10.1038/nclimate2174, 2014.

PAGES 2k Consortium: Continental-scale temperature variability during the past two millennia, Nat. Geosci., 6, 339-346, https://doi.org/10.1038.ngeo1797, 2013.

Peters, M. E. and Higuera, P. E.: Quantifying the source area of macroscopic charcoal with a particle dispersal model, Quat. Res., 67, 304-10, https://doi.org/10.1016/j.yqres.2006.10.004, 2007.

Petrenko, V. V., Smith, A. M., Schaefer, H., Riedel, K., Brook, E., Baggenstos, D., Harth, C., Hua, Q., Buizert, C., Schilt, A., Fain, X., Mitchell, L., Bauska, T., Orsi, A., Weiss, R. F., and Severinghaus, J. P.: Minimal geological methane emissions during the Younger Dryas-Preboreal abrupt warming event, Nature, 548, 443-446, 2017.

Power, M.J., Ortiz, N., Marlon, J., Bartlein, P. J., Harrison, S. P., Mayle, F., Ballouche, A., Bradshaw, R., Carcaillet, C., Cordova, C., Mooney, S., Moreno, P., Prentice, I. C., Thonicke, K., Tinner, W., Whitlock, C., Zhang, Y., Zhao, Y., Anderson, R. S., Beer, R., Behling, H., Briles, C., Brown, K, Brunelle A., Bush, M., Clark, J., Colombaroli, D., Chu, C. Q., Daniels, M., Dodson, J., Edwards, M. E., Fisinger, W., Gavin, D. G., Gobet, E., Hallett, D. J., Higuera, P., Horn, S., Inoue, J., Kaltenrieder, P., Kennedy, L., Kong, Z. C., Long, C., Lynch, J., Lynch, B., McGlone, M., Meeks, S., Meyer, G., Minckley, T., Mohr, J., Noti, R., Pierce, J., Richard, P., Shuman, B. J., Takahara, H., Toney, J., Turney, C., Umbanhower, C., Vandergoes, M., Vanniere, B., Vescovi, E., Walsh, M., Wang, X., Williams, N., Wilmshurst, J., and Zhang, J. H.: Changes in fire activity since the LGM: an assessment based on a global synthesis and analysis of charcoal data, Clim. Dynam., 30, 887-907, https://doi.org/10.1007/s00382.00.0334x, 2008.

Power, M. J., Marlon, J. R., Bartlein, P. J., and Harrison, S. P.: Fire history and the Global Charcoal Database: A new tool for hypothesis testing and data exploration, Palaeoclim., Palaeogeog. Palaeoecol., 291, 52-59, https://doi.org/10.1016/j.palaeo.2009.09.014, 2010.

Prentice, I. C.: Pollen representation, source area, and basin size: toward a unified theory of pollen analysis, Quat. Res., 23, 76-86, https://doi.org/10.1016/0033-5894(85)90073-0, 1985.

Prentice, I. C., Farquhar, G. D., Fasham, M. J. R., Goulden, M. L., Heimann, M., Jaramillo, V. J., Kheshgi, H. S., Le Quéré, C., Scholes, R. J., and Wallace, D. W. R.: The carbon cycle and atmospheric carbon dioxide. In: Climate Change 2001: The Scientific Basis, edited by: Houghton, J. T., Ding, Y., Griggs, D. J., Noguer, M., van der Linden, P. J., Dai, X., Maskell, K., and Johnson, C. A., Cambridge University Press, Cambridge, 183-237, 2001.

Prentice, I. C., Kelley, D. I., Foster, P. N. Friedlingstein, P., Harrison, S. P., and Bartlein, P. J.: Modeling fire and the terrestrial carbon balance, Glob. Biogeochem. Cy., 25, GB3005, https://doi.org/10.1029/2010GB003906, 2011. 
R Core Team. R: A language and environment for statistical computing. R Foundation for Statistical Computing, Vienna, Austria, https://www.r-project.org/, (last access: 16 February 2018), 2016.

Randerson, J. T., van der Werf, G. R., Giglio, L., Collatz, G. J., and Kasibhatla, P. S.: Global Fire Emissions Database, Version 4, (GFEDv4), ORNL DAAC, Oak Ridge, Tennessee, USA, https://doi.org/10.3334/ORNLDAAC/1293, 2015.

Roe, G.: Feedbacks, timescales, and seeing red, Annu. Rev. Earth Planet. Sci., 37, 93-115, https://doi.org/10.1146/annurev.earth.061008.134734, 2009.

Rubino, M., D’Onofrio, A., Seki, O., and Bendle, J. A.: Icecore records of biomass burning, Anthrop. Rev., 3, 140-162, https://doi.org/10.1177/2053019615605117, 2016.

Sapart, C. J., Monteil, G., Prokopiou, M., van der Wal, R. S. W., Kaplan, J. O., Sperlich, P., Krumhardt, K. M., van der Veen, C., Houweling, S., Krol, M. C., Bluneir, T., Sowers, T., Martinerie, P., Witrant, E., Dahl-Jensen, D., and Röckmann, T.: Natural and anthropogenic variations in methane sources during the past two millennia, Nature, 490, 85-88, https://doi.org/10.1038/nature11461, 2012.

Schwietzke, S. Sherwood, O. A., Bruhwiler, L. M. P., Miller, J. B., Etiope, G., Dlugokencky, E. J., Michel, S. E., Arling, V. A., Vaughn, B. H., White, J. W. C., and Tans, P. P.: Upward revision of global fossil fuel methane emissions based on isotope database, Nature, 538, 88-91, https://doi.org/10.1038/nature19797, 2016.

Shi, Y., Matsunaga, T., Saito, M., Yamaguchi, Y., and Chen, $\mathrm{X}$ : Comparison of global inventories of $\mathrm{CO}_{2}$ emissions from biomass burning during 2002-2011 derived from multiple satellite products, Environ. Poll., 206, 479-487, https://doi.org/10.1016/j.envpol.2015.08.009, 2015.

Sugita, S.: Pollen representation of vegetation in Quaternary sediments: Theory and method in patchy vegetation, J. Ecol., 82, 881-897, https://doi.org/10.2307/2261452, 1994. van der Werf, G. R., Randerson, J. T., Giglio, L., Collatz, G. J., Mu, M., Kasibhatla, P. S., Morton, D. C., DeFries, R. S., Jin, Y., and van Leeuwen, T. T.: Global fire emissions and the contribution of deforestation, savanna, forest, agricultural, and peat fires (1997-2009), Atmos. Chem. Phys., 10, 11707-11735, https://doi.org/10.5194/acp-10-11707-2010, 2010.

van der Werf, G. R., Peters, W., van Leeuwen, T. T., and Giglio, L.: What could have caused pre-industrial biomass burning emissions to exceed current rates?, Clim. Past, 9, 289-306, https://doi.org/10.5194/cp-9-289-2013, 2013.

van der Werf, G. R., Randerson, J. T., Giglio, L., van Leeuwen, T. T., Chen, Y., Rogers, B. M., Mu, M., van Marle, M. J. E., Morton, D. C., Collatz, G. J., Yokelson, R. J., and Kasibhatla, P. S.: Global fire emissions estimates during 1997-2016, Earth Syst. Sci. Data, 9, 697-720, https://doi.org/10.5194/essd-9-697-2017, 2017.

Vose, R. S., Arndt, D., Banzon, V. F., Easterling, D. R., Gleason, B., Huang, B., Kearns, E., Lawrimore, J. H., Menne, M. J., Peterson, T. C., Reynolds, R. W., Smith, T. M. Williams, C. N., Jr., and Wuertz, D. L.: NOAA's merged land-ocean surface temperature analysis, B. Am. Meterol. Soc., 93, 16771685, https://doi.org/10.1175/BAMS-D-11-00241.1, 2012.

Wang, Z., Chappellaz, J., Park, K., and Mak, J. E.: Large variations in southern hemisphere biomass burning during the last 650 years, Science, 330, 1663-1666, https://doi.org/10.1126/science.1197257, 2010.

Ward, D. S., Kloster, S., Mahowald, N. M., Rogers, B. M., Randerson, J. T., and Hess, P. G.: The changing radiative forcing of fires: global model estimates for past, present and future, Atmos. Chem. Phys., 12, 10857-10886, https://doi.org/10.5194/acp-1210857-2012, 2012.

Wenzel, S., Cox, P. M., Eyring, V., and Friedlingstein, P.: Emergent constraints on climate-carbon cycle feedbacks in the CMIP5 Earth system models, J. Geophys. Res.-Biogeosci., 119, 794807, https://doi.org/10.1002/2013JG002591, 2014. 